\title{
A multi-criteria approach to the selection of the optimal investment alternative with software support
}

\section{Вишекритеријумски приступ избору оптималне инвестиционе алтернативе уз софтверску подршку}

\author{
Zoran Nešić \\ zoran.nesic@ftn.kg.ac.rs \\ Dragana Radojičić \\ dragana@fam.tuwien.ac.at

\section{Radomir Šalić} \\ Metropolitan University, Belgrade, Serbia, \\ radomir.salic@metropolitan.ac.rs
}

University of Kragujevac, Faculty of Technical Sciences, Cacak, Serbia,

TU Wien, Institute of Statistics and Mathematical Methods in Economics, Wien, Austria,

\begin{abstract}
This paper proposes some possibilities of implementing information technology in investment management. The paper deals with the choice of the optimal investment alternative out of a series of alternatives compared, evaluated in the system of different and heterogeneous criteria with different requirements for the extremization with different relative significance. The analysis of the criteria was performed from the aspect of production capacities, investment value, the required number of employees, the internal rate of return, investment maintenance, as well as the logistical and technological levels. The choice of the optimal alternative was made by the multicriteria decision-making methods with developed software support for this purpose. The results indicate the agreement of the optimal alternative, i.e. the rank of the compared alternatives, through the parallel application of the two multicriteria decision methods. The compromise programming method and a modified approach to the Promethee multicriteria decision-making method that allows the analysis of an unlimited number of different preferential functions are applied in the paper. The application of certain preferential functions is analyzed from the point of view of individual criteria applied in this paper. The paper presents the general options for choosing investment alternatives from several most significant aspects, with an analysis of the preferences of the individual criteria. The application of the presented methodology enables a sophisticated approach to criteria analysis. On the other hand, the software solution developed for this purpose enables simplicity and applicability in practical conditions of use.
\end{abstract}

Keywords: investment management, information technology, decision support systems, decision-making and optimization, compromise programming

JEL classification: C61, D25, G11

Сажетак: У овом раду су приказане неке могућности примене информационих технологија у управљању инвестицијама. Рад се односи на избор оптималне инвестиционе алтернативе од низа упоређиваних,

1 This study was supported by the Ministry of Education, Science and Technological Development of the Republic of Serbia, and these results are parts of the Grant No. 451-03-68/2020-14/200132 with University of Kragujevac - Faculty of Technical Sciences Čačak.

Corresponding author 
оцењених у систему различитих и разнороднох критеријума са различитим захтевима за екстремизацијом са различитим релативним значајем. Анализа критеријума је извршена са аспекта производних капацитета, вредности инвестиције, потребног броја ангажованих радника, интерне стопе рентабилности, инвестиционог одржавања као и логистичког и технолошког нивоа. Избор оптималне алтернативе је извршен методама вишекритеријумског одлучивања уз развијену софтверску подршку за ту намену. Резултати указују на сагласност оптималне алтернативе, односно ранга упоређиваних алтернатива упоредном применом две методе вишекритеријумског одлучивања. У раду је примењена метода компромисног програмирања и примењен је модификован приступ Promethee методе вишекритеријумског одлучивања која омогућава анализу неограниченог броја различитих преференцијских фрункција. Примена појединих преференцијских функција је анализирана са аспекта појединих примењених критеријума у овом раду. Рад приказује опште могућности избора инвестиционих алтернатива са више најзначајнијих аспекта, уз анализу преференција појединих критеријума. Применом приказане методологије омогућава се софистицирани приступ анализи критеријума. Са друге стране, за ту намену развијено софтверско решење омогућава једноставност и применљивост у практичним условима коришћења.

Кључне речи: управљање улагањима, информационе технологије, системи за подршку одлучивању, доношење одлука и оптимизација, компромисно програмирање

JEЛ класификација: C61, D25, G11

\section{Introduction}

Investment is one of the most important factors in managing the development process of manufacturing company. Investment management decisions have a long-term effect on the business, involve a large volume of financial investments and have a high risk for the entire business. It can rightly be considered that financial investment is one of the biggest decisions in order to modernize and expand production capacities. Therefore, special attention should be paid to this issue.

The analysis of the production process from an economic point of view is a key factor in considering the required financial investments (Locke \& Wellhausen, 2014). Many authors rightly attach great importance to this issue, starting from the regional aspect (Winden, Berg, Carvalho \& Tuijl, 2010) to analyzing the dynamics of the economic component of production (Landesmann \& Scazzieri, 2009).

Paul van Loon (2012) emphasizes the connection between production, finance and investment as an indispensable and comprehensive activity of production management. In this regard, many authors highlight various aspects of investment, starting with production development (Bellgran \& Säfsten, 2009), the role of foreign investment in the economy (Kowalewski \& Weresa Herausgeber, 2008) macro and international economic (Piros \& Pinto, 2013).

When analyzing investments, it is crucial to find the optimal investment alternative. The application of operational research methodologies in this regard is of particular importance (Piros \& Pinto, 2013; Ravi Ravindran, 2016; Ravi Ravindran, 2008; Tomlinson \& Kiss, 2013; Bell, Warwick \& Galbraith, 2013). Sodhi and Tang (2010) emphasize the necessity of applying operations research in the whole of management science by analyzing various approximation theories and mathematical methods. 
Making business decisions for the purpose of making investments is the choice of the optimal alternative based on a number of possible ones. Also, the optimal alternative needs to be determined on the basis of a number of criteria, basically opposed, expressed in different units, with different requirements for maximization and minimization. The problem is further compounded by the different meanings of certain criteria that need to be considered. It is practically possible to make such business decisions only by applying multi-criteria optimization and various scientifically based decision making methodologies (Shapira, 2002; Crozier, Ranyard \& Svenson, 2002; Adair \& Adair, 1999; Cook, Noyes \& Masakowski, 2007; Roth \& Mullen, 2002; Streifer \& Goens, 2004). Al-Shammari and Masri (2015) point out the importance of modern methodologies for decision making in finance as well as the analysis of their theoretical and methodological achievements.

In choosing the optimal alternative, this paper used multi-criteria decisionmaking methodologies Compromise Ranking (Opricovic, 1992) and PROMETHEE (Brans \& Vincke, 1985). Due to the distinctive methodology of preference expression according to individual criteria, the emphasis was placed on the PROMETHEE method, which enables visual display of preference expression through graphical preference functions. In contrast to the original methodology, developed by Brans and Vincke, which allows for the application of six generalized preference functions, a modified PROMETHEE method was applied in the paper using the Universal preference function (Radojicic, Zizovic, Nesic \& Vesic Vasovic, 2013). With this approach it is possible to generate an unlimited number of functions, which can express the preference of the decision maker in a much more sophisticated way.

Contemporary requirements of decision-makers, on the one hand, relate to the application of increasingly complex multi-criteria decision-making methodologies, while, on the other hand, the requirements relate to their simpler application, aligned with practical needs. In this respect, decision support systems (Burstein \& Holsapple, 2008; Power, 2002; Frederic, 2008; Ravindranath, 2003; Herasymowych \& Senko, 2008; Janakiraman \& Sarukesi, 2008) and the use of information technology are inevitable.

Numerous authors emphasize the importance of applying multi-criteria optimization when choosing the best investment alternative, confirming the need to take into account a number of different relevant criteria (Puska, Beganovic, \& Sadic, 2018). Suganthi (2018) emphasizes the practical importance of applying the integrated fuzzy AHP, VIKOR / DEA methodology in the broader field of investment decision making. One of the proposals for improving the application of multi-criteria optimization that affects the calculation of economic efficiency of investments refers to the research of its application under uncertainty (Shvetsova, Rodionova, \& Epstein, 2018). Research shows the successful application of multi-criteria optimization in choosing the best investment alternative using different methodologies such as 
ELECTRA (Kozik, 2017), fuzzy approach (Sudharsan, \& Ezhilmaran, 2016; Rebiasz, \& Maciol, 2015) to a systemic approach using graphic interpretation of results (Szafranko, 2017). The application of this methodology can also refer to certain segments - stocks, bonds, mutual funds, which individually influence the choice of the best investment alternative (Chen, Wang, \& Yu, 2014). One of the interesting approaches includes a psychological approach in the application of multi-criteria decision-making methods, which refers to the risk profile (Looney, \& Hardin, 2015). This paper emphasizes the importance of the application of information technology in support of multi-criteria decision-making, which is confirmed by numerous authors proving the connection between information quality and investment efficiency (Moradi, Jafari, Ehteshamnejad, \& Asaadi, 2019).

\section{Selection of the optimal investment alternative}

The first and most important step in the implementation of the multi-criteria decisionmaking methodology is the choice of the alternatives and criteria to be considered. This paper presents an example of choosing the optimal alternative over the seven compared. The criteria for choosing the optimal alternative are of diverse character, with different requirements for minimization and maximization.

Criterion analysis was performed in terms of production capacity, value of investment, required number of engaged employees, internal profitability, investment maintenance as well as logistical and technological level. Figure 1 shows the form of a software solution for entering individual alternatives and their values in relation to individual criteria.

Figure 1: The values of alternatives in relation to certain criteria

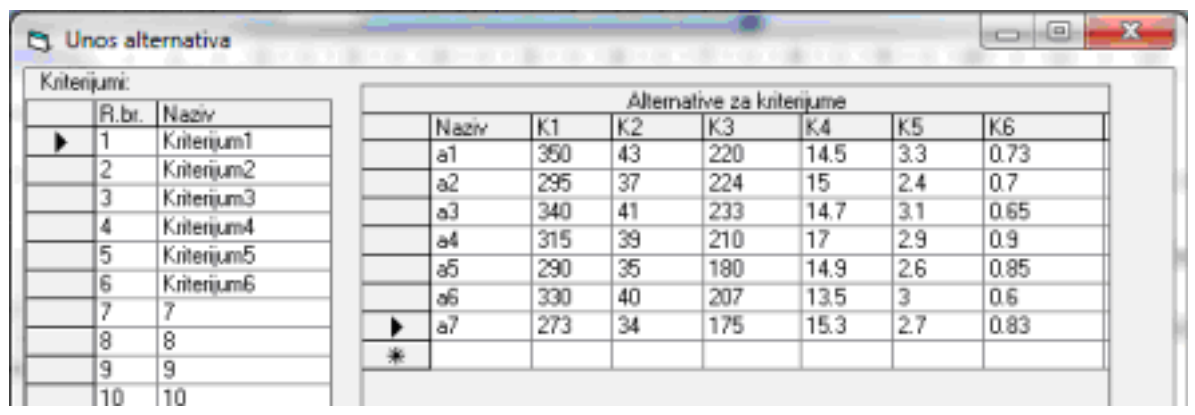

In addition to the selection of particular alternatives and criteria, criteria analysis is the second most important step in the application of the multicriteria analysis method. The application of the modified PROMETHEE method of multicriteria decision making enables a graphical analysis of an unlimited number of preference functions and sophisticated expression of the importance of certain criteria. The parameters for expressing and analyzing preferences are as follows: 
- $\quad$ - Request (MaxMin)

- $\quad-\alpha$ and $\beta$ - preference intensity parameters

- $-p$ - the limit of change in preference intensity,

- $-\mathrm{q}$ - the limit of preference

- $-\mathrm{m}$ - parameter

- - Relative importance

Figure 2 shows the analysis of production capacity criteria (Request $=$ MAX, $m$ $=0.5, \alpha=3, \beta=0.8, p=40, q=60$, Rel. imp. $=0.2)$ Figure 3 shows the analysis of investment value criteria (Request $=$ MIN, $\mathrm{m}=1, \alpha=1, \beta=1, \mathrm{p}=15, \mathrm{q}=15$, Rel. imp. $=0.2$ ).

Figure 2: Analysis of production capacity criteria

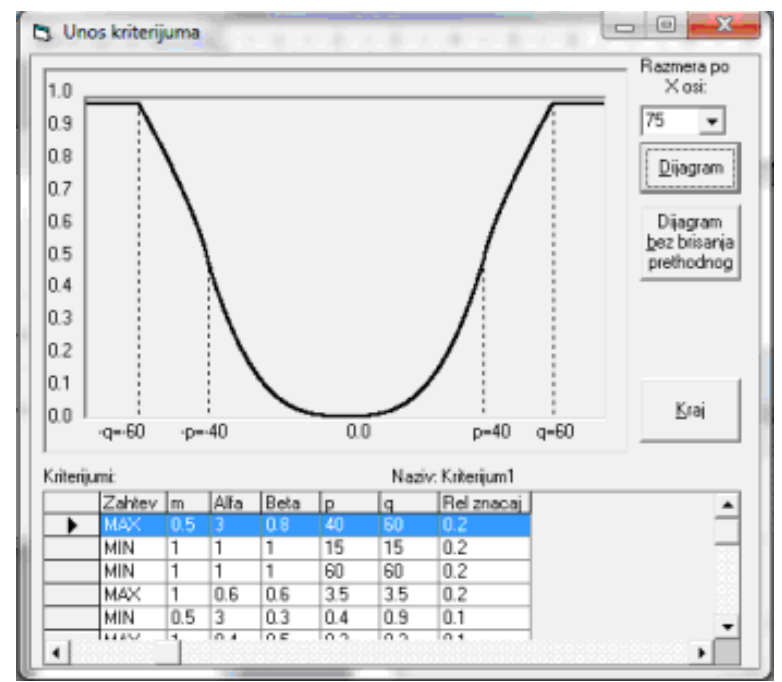


Figure 3: Analysis of investment value criteria

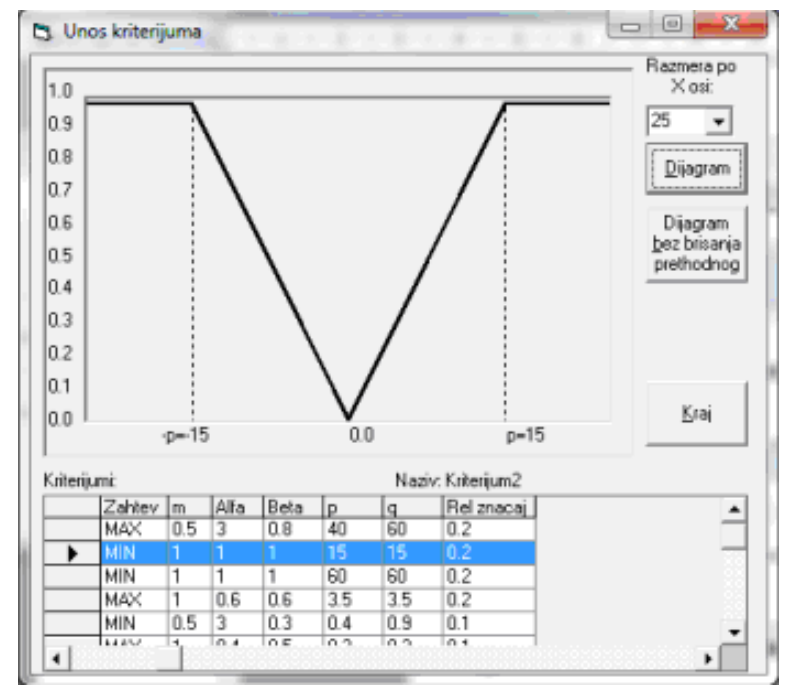

Figure 4 shows the criterion analysis of the number of employees required (Request $=$ MIN, $m=1, \alpha=1, \beta=1, p=60, q=60$, Rel. imp. $=0.2$ ) Figure 5 shows the analysis of internal criteria profitability rates (Request $=\mathrm{MAX}, \mathrm{m}=1, \alpha=0.6, \beta=$ $0.6, \mathrm{p}=3.5, \mathrm{q}=3.5$, Rel. imp. $=0.2$ )

Figure 4: Criteria analysis of required number of employees

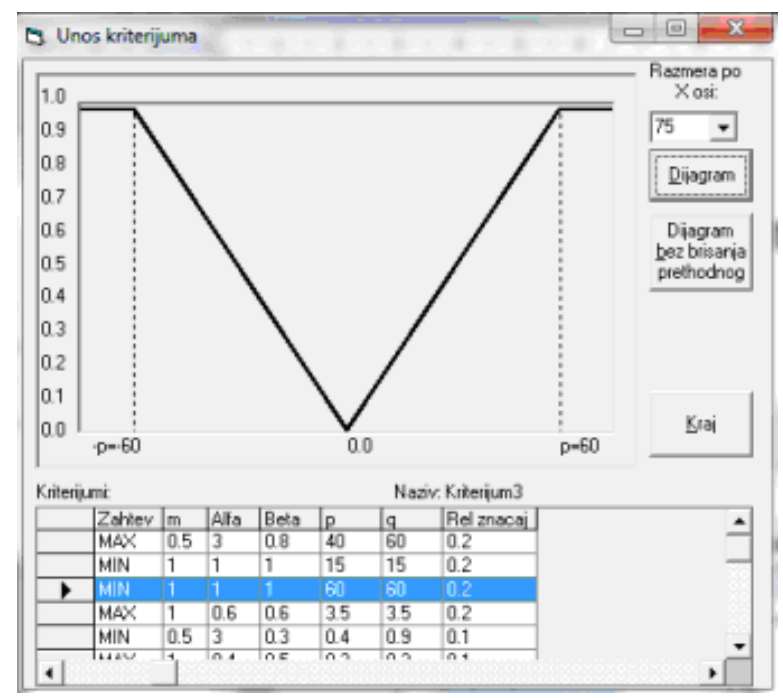


Figure 5: Analysis of the criteria of internal rate of return

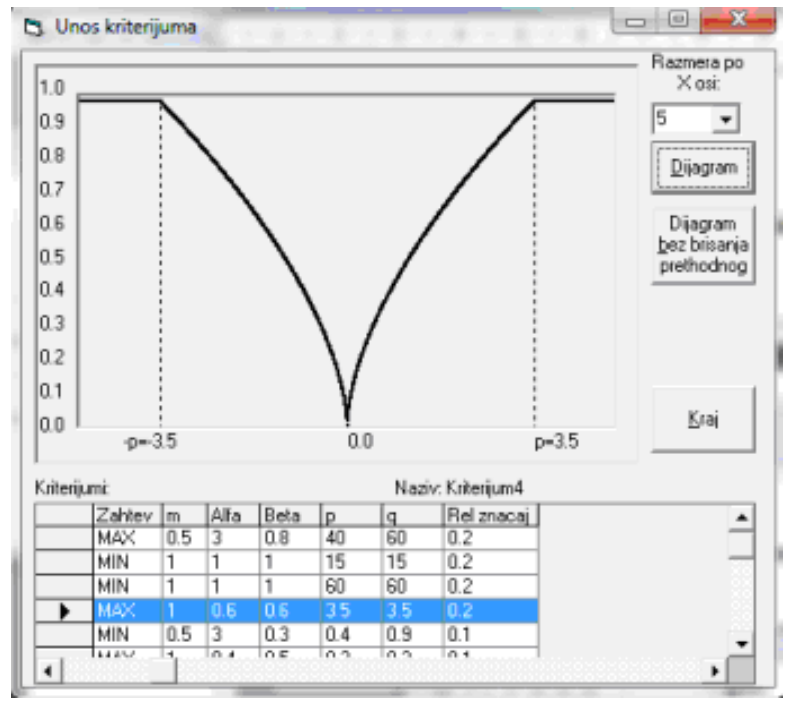

Figure 6 shows the analysis of the investment maintenance criterion (Request $=$ MIN, $\mathrm{m}=0.5, \alpha=3, \beta=0.3, \mathrm{p}=0.4, \mathrm{q}=0.9$, Rel. imp. $=0.1$ ) Figure 7 shows the analysis of the logistic and technological level criterion (Request $=$ MAX, $\mathrm{m}=1, \alpha=$ $0.4, \beta=0.5, \mathrm{p}=0.3, \mathrm{q}=0.3$, Rel. imp. $=0.1$ )

Figure 6: Analysis of the criteria of investment maintenance

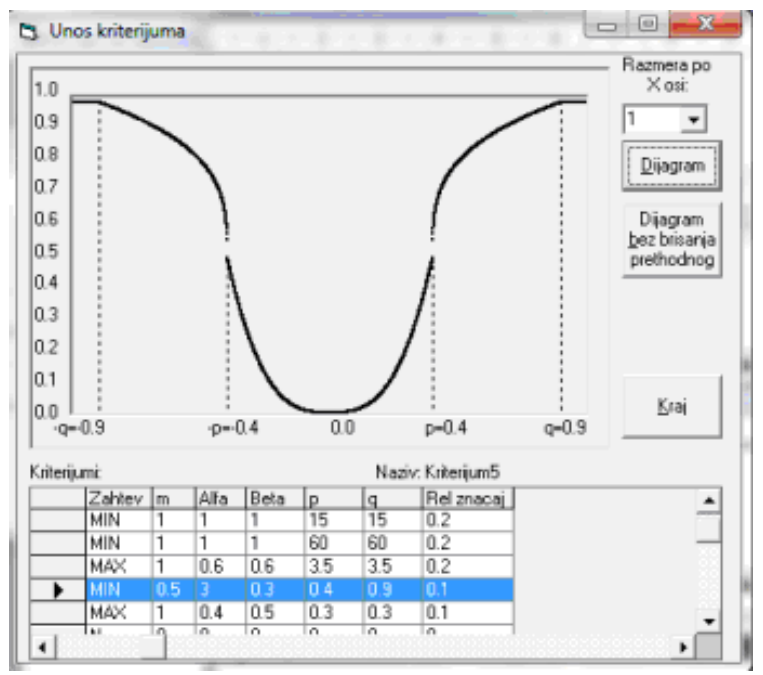


Figure 7: Logistic and technological level criteria analysis

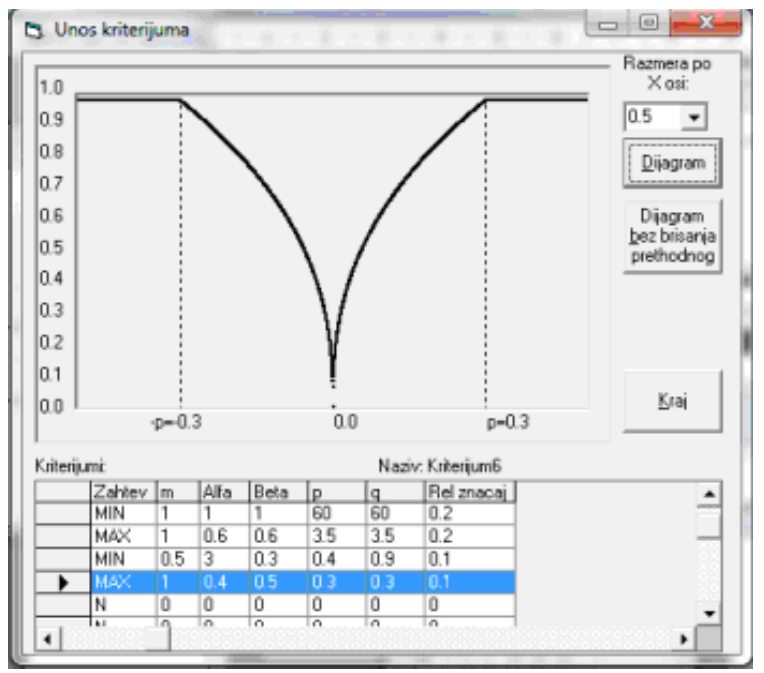

The production capacity criterion is one of the most important criteria that needs to be analyzed with great care. Its importance is reflected in large investment funds. Therefore, the preference function is expressed in higher values - faster growth of the preference function is expressed between the boundaries of change of preference intensity and the preference boundary. Higher values of financial investments in production capacities require a much higher level of preference in this area.

The investment value criterion is expressed as a linear function with no boundaries of preference intensity change. Equal growth of a preference function signifies an equal importance of preference throughout the preference space.

Similar to the previous one, the criterion of the required number of employees hired is expressed by a linear function of preference with equal growth and significance throughout the preference space. The criterion of internal rate of return and the criterion of logistical technological level is expressed by a function that emphasizes faster growth and importance for the smallest values in the preference space.

Figure 8 shows the rank results of the alternatives of the two multicriteria decision-making methods used, with the results indicating significant agreement of the rank of compared alternatives:

- - PROMETHEE (a4, a5, a7, a2, a1, a3, a6)

- $\quad$ - Compromise Programming (a4, a5, a7, a2, a1, a6, a3) 
Figure 8: Results of the ranking of alternative

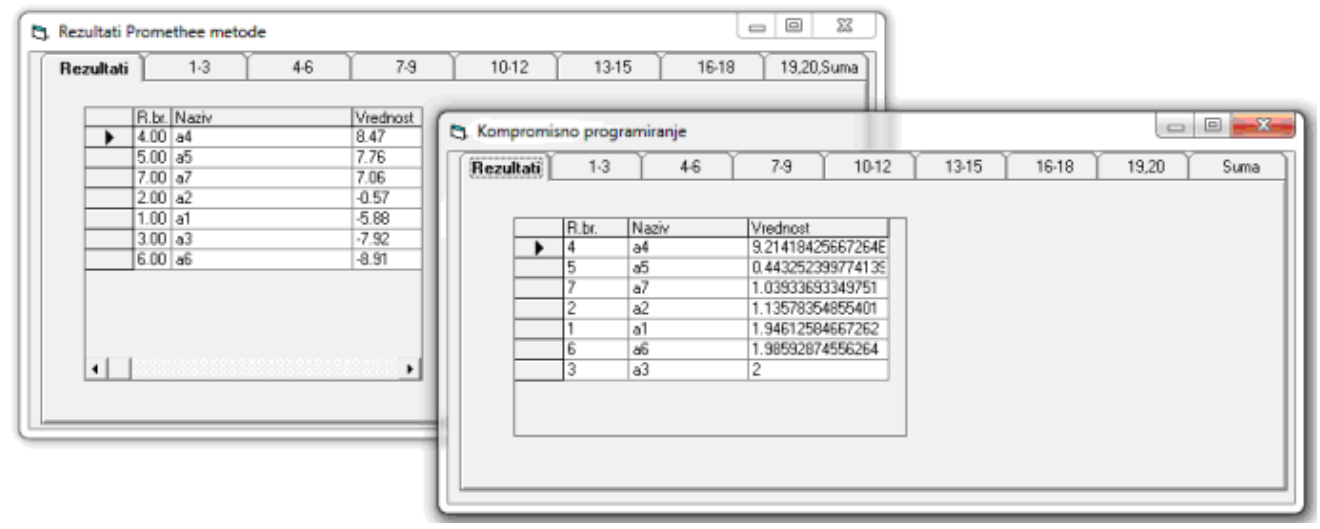

The importance of applying the presented multicriteria decision-making methodology is demonstrated because of the need to determine the best or optimal alternative based on a large number of possible as well as on a number of different criteria. Mathematical models play a significant role in this regard as the only way to select them. However, the significant role of information technology as their support should also be emphasized. The presented software solution enables the use of complex mathematical models, graphical or visual representation of the expression of preferences through preference functions. On the other hand, the decision-maker is enabled to use it simply, speed, eliminates the possibility of error.

It is indisputable that software support, as well as the application of information technology in a broad sense, is an indispensable element in the practical use of multicriteria decision-making methodology. The application of information technology in the broad sense is especially important in obtaining a wide range of relevant information from internal and external sources that enable the decision maker to select potential alternatives and criteria themselves and then obtain the value of alternatives according to individual criteria, and more.

The application of the presented software solution enables many practical applications in the analysis of the evaluation of particular criteria, the comparative presentation of preference functions and the analysis of their different alternative values.

\section{Conclusion}

This paper presents an approach in choosing the optimal investment alternative in industrial production. Consideration is based on the application of multi-criteria decision-making methodology with appropriate software support. The paper presents a practical methodological approach to selecting the optimal investment alternative from 
a series of comparisons. The alternatives were considered in a system of different and heterogeneous criteria with different requirements for extremization of different relative importance.

The paper illustrates the most important investment decision criteria that can be applied to various real-world problems. Also, some possibilities of modern multicriteria decision-making methodology and a specific approach to expressing preferences of particular criteria were highlighted. The results indicate the agreement of the optimal alternative, that is, the rank of the compared alternatives, by the comparative application of two multicriteria decision-making methods. The software solution developed for this purpose enables simplicity and applicability in practical conditions of use.

\section{Acknowledgment}

Some parts of the paper have been presented at the Third International Scientific Conference - ITEMA 2019 (http://www.itema-conference.com)

\section{References}

Adair, J., \& Adair, J. E. (1999). Decision Making and Problem Solving, London: CIPD Publishing.

Al-Shammari, M., \& Masri, H. (2015). Multiple Criteria Decision Making in Finance, Insurance and Investment, Cham: Springer.

Bell, G., Warwick, J., \& Galbraith, P. (2013). Higher Education Management and Operational Research: Demonstrating New Practices and Metaphors, Rotterdam: Springer Science \& Business Media.

Bellgran, M., \& Säfsten, E. K. (2009). Production Development: Design and Operation of Production Systems, London: Springer Science \& Business Media.

Brans, J. P., \& Vincke Ph. (1985). A Preference ranking organization method (The Promethee Method for Multiple Criteria Decision Making, Management Science, 31, 647-656.

Burstein, F., \& Holsapple, C. W. (2008). Handbook on Decision Support Systems 1: Basic Themes, Berlin: Springer Science \& Business Media.

Chen, ANK., Wang, SY., \& Yu, PL. (2014). Evaluating multi-criteria ratings of financial investment options, International Review of Economics \& Finance, 31., 4658. Doi: http://doi.org/10.1016/j.iref.2013.12.003

Cook, M. J., Noyes, J. M., \& Masakowski, Y. (2007). Decision Making in Complex Environments, England: Ashgate Publishing, Ltd. 
Crozier, R., Ranyard, R., \& Svenson, O. (2002). Decision Making: Cognitive Models and Explanations, London: Routledge.

Frederic, A. (2008). Encyclopedia of Decision Making and Decision Support Technologies, USA: IGI Global.

Herasymowych, M., \& Senko H. (2008). Decision Support System: Quick Reference Guide, Calgary: MHA Institute, Incorporated.

Janakiraman, V. S., \& Sarukesi, K. (2008). Decision Support Systems, New Delhi: PHI Learning Pvt. Ltd.

Kowalewski, O., \& Weresa Herausgeber, M. A. (2008). The Role of Foreign Direct Investment in the Economy, München: Rainer Hampp Verlag.

Kozik, R. (2017). Application of Multi-Criteria Decision Analysis in Selecting of Sustainable Investments, Proceedings of the International Conference on Numerical Analysis and Applied Mathematics, Rhodes, Greece, Vol. 1863, Article No. 230016. Doi: http://doi.org/10.1063/1.4992401

Landesmann, M. A., \& Scazzieri, R. (2009). Production and Economic Dynamics, Cambridge: Cambridge University Press.

Locke, R. M., \& Wellhausen R. L. (2014). Production in the Innovation Economy, London: MIT Press.

Loon, P. V. (2012). A Dynamic Theory of the Firm: Production, Finance and Investment, Berlin: Springer Science \& Business Media.

Looney, CA., \& Hardin, AM. (2015). Multi-Criteria Decision Support for Investment Decisions: Examining the Interactive Effects of Risk Profile, Information Horizon, and Prospect Format, 48th Annual Hawaii International Conference on System Sciences (HICSS), Kauai, HI., 1240-1247. Doi: http://doi.org/10.1109/HICSS.2015.151

Moradi, M., Jafari, SM., Ehteshamnejad, E., \& Asaadi, A. (2019). Multi-Criteria Statistical-Based Analysis On The Effect Of Accounting Information Quality On Efficiency Of Investment By Emphasizing Upon Auditor Specialty In Industry In Accepted Corporations In Tehran Stock Exchange, International Transaction Journal Of Engineering Management \& Applied Sciences \& Technologies, 10(8), 1105-1114. Doi: http://doi.org/10.14456/ITJEMAST.2019.105

Opricovic, S. (1992). Optimizacija sistema, Belgrade: Građevinski fakultet.

Piros, C. D., \& Pinto, J. E. (2013). Economics for Investment Decision Makers: Micro, Macro, and International Economics, New Jersey: John Wiley \& Sons.

Power, D. J. (2002). Decision Support Systems: Concepts and Resources for Managers, USA: Greenwood Publishing Group. 
Puska, A., Beganovic, A., \& Sadic, S. (2018). Model for Investment Decision Making by Applying the Multi-Criteria Analysis Method, Serbian Journal Of Management, 13(1), 7-28. Doi: http://doi.org/10.5937/sjm13-12436

Radojicic, M., Zizovic, M., Nesic, Z., \& Vesic Vasovic, J. (2013). Modified approach to PROMETHEE for multi-criteria decision-making, Maejo International Journal of Science and Technology, 7(3), 408-421. Doi: http://doi.org/10.14456/mijst.2013.34

Ravi Ravindran, A. (2008). Operations Research Applications, New York: CRC Press.

Ravi Ravindran, A. (2016). Operations Research and Management Science Handbook, New York: CRC Press.

Ravindranath, B. (2003). Decision Support Systems and Data Warehouses, New Delhi: New Age International.

Rebiasz, B., \& Maciol, A. (2015). Comparison of Classical Multi-Criteria Decision Making Methods with Fuzzy Rule-Based Methods on the Example of Investment Projects Evaluation, 7th KES International Conference on Intelligent Decision Technologies (KES-IDT), Sorrento, Italy, Vol. 39., 549-561, Doi: http://doi.org/10.1007/978-3-319-19857-6_47

Roth, B. M., \& Mullen, J. D. (2002). Decision Making: Its Logic and Practice, USA: Rowman \& Littlefield.

Shapira, Z. (2002). Organizational Decision Making, Cambridge: Cambridge University Press.

Shvetsova, OA., Rodionova, EA., \& Epstein, MZ. (2018). Evaluation of Investment Projects Under Uncertainty: Multi-Criteria Approach Using Interval Data, Entrepreneurship and Sustainability Issues, 5(4), 914-928. Doi: http://doi.org/10.9770/jesi.2018.5.4(15)

Sodhi, M. M. S., \& Tang, C. S. (2010). A Long View of Research and Practice in Operations Research and Management Science: The Past and the Future, New York: Springer Science \& Business Media.

Streifer, P. A., \& Goens G. A. (2004). Tools and Techniques for Effective Data-driven Decision Making, UK: R\&L Education.

Sudharsan, S., \& Ezhilmaran, D. (2016). Weighted arithmetic average operator based on interval-valued intuitionistic fuzzy values and their application to multi criteria decision making for investment, Journal of Information \& Optimization Sciences, 37(2), 247-260. Doi: http://doi.org/10.1080/02522667.2015.1107329

Suganthi, L. (2018). Multi-expert and multi-criteria evaluation of sectoral investments for sustainable development: An integrated fuzzy AHP, VIKOR/DEA methodology, 
Sustainable Cities and Society, 43, 144-156. Doi:

http://doi.org/10.1016/j.scs.2018.08.022

Szafranko, E. (2017). Methodology in the Assessment of Construction and

Development Investment Projects, Including the Graphic Multi-Criteria Analysis - a

Systemic Approach, World Multidisciplinary Civil Engineering-Architecture-Urban Planning Symposium (WMCAUS), Prague, Czech Republic, Vol. 245, Article No.

UNSP 072026. Doi: http://doi.org/10.1088/1757-899X/245/7/072026

Tomlinson, R., \& Kiss, I. (2013). Rethinking the Process of Operational Research \& Systems, Oxford: Elsevier.

Winden, W. V., Berg, L. V. D., Carvalho, L., \& Tuijl, E. V. (2010). Manufacturing in the New Urban Economy, London, New York: Routledge. 